\title{
World War II Narratives in Contemporary Germany and Japan: How University Students Understand Their Past
}

Ingvild Bode (University of Kent) \& Seunghoon Emilia Heo (Sophia University)

[This is the post-print version of an article accepted for publication at International Studies Perspectives, doi: 10.1093/isp/ekw011]

This article explores narratives university students in Germany and Japan tell about World War II. Studying these narratives offers insights into how conflict reality and knowledge are socially constructed. Scholars in reconciliation and memory studies have so far mainly focused on the differences between how Germany and Japan choose to remember their wartime pasts in history curricula and textbooks. However, little is known about how far these official versions of history are reproduced or challenged by university students. Working with data collected through an online survey, our findings address this question by making two arguments: first, the depth of World War II knowledge and the variety of knowledge sources students were exposed to affect whether students engage in a reflective or non-reflective characterization of their home countries' role. This appears to be primarily influenced by the national knowledge environment students find themselves in. Second, while students surveyed tended to reproduce official narratives, both Japanese and German students also displayed critical engagement with World War II history teaching and knowledge in their countries.

Keywords: narratives, World War II, university students, history education

Acknowledgements: We are grateful for the insightful comments of three anonymous reviewers as well as ISP editor Laura Neack and the valuable feedback we received when presenting the paper at the 2015 conference on "Narratives of Peace and Conflict" at Liverpool Hope University and at the German Institute for Japanese Studies, Tokyo. Finally, we want to express our gratitude to all students who participated in our survey.

In 2015, 70 years had passed since World War II (WWII) came to an end across Europe and Asia. ${ }^{1}$ How the war's two main aggressors, Germany and Japan, have remembered their wartime deeds and faced their past have repeatedly been compared in studies of reconciliation and memory (e.g. Dahl 2008; Bindenagel 2006; Lebow, Kansteiner, and Fogu 2006; Olick and Levy 1997; L. Hein and Selden 2000; Conrad 2003; Berger 2012; P. Hein 2010). Remembering the events of World War II becomes more challenging as they recede further into history. Only Germany and Japan's oldest generation witnessed the war themselves. By definition, we cannot remember something we did not experience. Instead,

\footnotetext{
${ }^{1}$ Although "Zweiter Weltkrieg" (World War II) is uniformly used in the German context, World War II has been referred to in different and contested ways in Japan. Immediately after 1945, "Pacific War" was used - a term later criticised because of its exclusive focus on the Japanese-US-American side of the conflict, leading to the introduction of the term "Asia Pacific War". Terminology still continues to be contested (Dierkes 2010, 150151).
} 
perceptions are shaped by what we have learned at school, what we have seen in the media, or what we have been told by contemporary witnesses. This ongoing dialogue between the past and the present becomes more testing as our states attempt to influence our understanding by choosing ways of remembering the past. Both Germany and Japan have therefore "created" official versions of history and narratives.

While much scholarly attention has been devoted to analyzing school curricula and how these are reflected in school textbooks, little is known about whether these official versions of history are reproduced, shared among, or challenged by university students: what do current German and Japanese students know about World War II? How do they characterize their countries' role during World War II? Are they satisfied with the ways history is being taught in their countries? Our article addresses these central questions by examining German $(\mathrm{N}=133)$ and Japanese $(\mathrm{N}=155)$ student narratives based on data collected through a mixed-structure online survey.

Considering these university student narratives is crucial because their perspectives are rarely heard but will inform their countries' future national images. Capturing how they understand their countries' wartime past can indicate reference for Japan and Germany's future outlook. Germany and Japan's wartime histories remain an important reference point for how they perceive themselves and are perceived by others. This dual public perception process of "self" and "other" affects (foreign) policy identity and planning (Hansen 2006). Links between the past and the present are particularly vivid in discourse about Japan and Germany's involvement in international interventions and about the extent of military deployments (Maull 1990). Domestically, these issues continue to be hotly debated and negotiated, especially in the context of constitutionally prescribed limits to the use of force. Globally, although core members of the international community initially appeared to contend that Germany and Japan cannot be trusted with the use of force, their (NATO) allies gradually encouraged them to increase military engagement since the late 1990s. The Japanese-US security agreement of 2015 prompting a re-interpretation of pacifist article 9 of the Japanese constitution under the Abe government underlines these developments.

By focusing on narrative understandings of history, this article offers a two-fold emphasis, first that what counts as historical knowledge is socially constructed. Second, our article seeks to highlight the centrality of the narrative form as a way of communicating human experience and as a pervasive feature of how humans make sense of the world (Kacowicz 
2005, 344; Shenhav 2006, 245; Suganami 1999, 381; Bode 2015, 47). These narratives, in particular when we talk about (past) conflict or war, contribute to shaping social reality.

The article is structured as follows: first, we map broad changes in how Germany and Japan have dealt with their World War II past, introduce the concept of narratives, and provide a brief review of relevant literature in order to situate our contribution. In a second part, we address methodological considerations, especially in relation to the design of the survey and the importance of autoethnograpy for our work. Third, we present our empirical findings on student knowledge, how student narratives depict their home countries, and whether students think history education should be changed. We conclude by summarizing our findings, outlining their wider implications, and suggesting further research in the field of narratives and international relations.

\section{Narratives of Germany and Japan's Wartime Past}

Comparing different ways in which Germany and Japan have dealt with their World War II past is not a new topic. It is well situated within a research field analyzing how various neighboring states have engaged with their conflictual past and in reconciliation efforts. Frequently studied cases include Turkey with Armenia and Greece, but particularly Germany's relations with France, Poland and Israel as well as Japan's relations with China and Korea have received much scholarly and media coverage. ${ }^{2}$ Attention surged in the year 2015 , which marked the $100^{\text {th }}$ anniversary of the Armenian Genocide, the $70^{\text {th }}$ anniversary of the end of WWII, and the $50^{\text {th }}$ anniversaries of German-Israeli as well as Korean-Japanese diplomatic relations.

Since the publication of Ian Buruma's The Wages of Guilt in 1995, scholars have analyzed various behavioral and structural differences in how Germany and Japan have attempted to come to terms with their violent pasts. They highlight the contrast between public expressions of guilt and denial ${ }^{3}$, political leaders' behavior, the impact of US foreign policy, national myth-making by political elites, the history textbook controversy, and governmental influence on creating official historical narratives (e.g. He 2009; Feldman 2012; Berger 2012; Rose 2008; Lind 2008; Gibney 2008). Historical narratives have featured

\footnotetext{
2 For a list of scholarly works on these interstate reconciliation cases, see Heo 2012.

${ }^{3}$ Reasoning behind these arguments leads back to Ruth Benedict's contested guilt cultures vs. shame cultures thesis (1946).
} 
as central tools for creating national identities and overall cohesion since the advent of the nation-state in the nineteenth-century (Durand and Kaempf 2014, 332; Nishino 2011, 29). War and conflict have been particularly prominent because many countries were built in violent struggles. The significance of narratives for creating nationhood has been highlighted by scholars such as Benedict Anderson and Eric Hobsbawn, writing about "imagined communities" and "the invention of tradition" (Hobsbawm and Ranger 1983; Anderson 1983). Based on this significance attached to historical narratives, it became a matter of national interest to govern how and what schools teach about a nation's history. Existing literature has analyzed examples of national history textbooks and educational curricula, mapping the changing nature of what counts as historical content or the "right" narrative throughout various eras, spanning from revisionism to political transformation (Durand and Kaempf 2014, 333; see also L Hein and Selden 2000; Chirot, Sin, and Sneider 2014; Conrad 2003; Han et al. 2012; Nozaki 2008; Cave 2013). This writing is also embedded in wider pedagogical debates on critical education (Apple 2002; Apple 1988) and how to teach history, specifically: should the focus be on content or critical thinking and how much content is needed in order to allow critical thinking and engagement with diverging historical evidence ${ }^{4}$ These questions are significant, because what counts as content or historical "fact" is narratively contested.

The changing narratives about World War II history in both Germany and Japan highlight this variable nature of historical knowledge. In the immediate post-1945 period, German textbooks remained largely silent about the Holocaust and German war crimes, featuring instead a narrative ascribing all responsibility and guilt to Hitler and the Nazi elite, while emphasizing the plight of German civilians (He 2009, 60). ${ }^{5}$ These narratives changed with educational reforms in the 1960s and 1970s that initiated a more detailed coverage of Nazi totalitarianism, leading to an eventual coming to terms with its Nazi past as a cornerstone of Germany's post-war national narrative (Soysal 2000; He 2009, 88-90). This consensus is mirrored in history textbooks, which, moreover, tend to promote critical engagement with

\footnotetext{
${ }^{4}$ We are indebted to an anonymous reviewer for bringing this point to our attention.

${ }^{5}$ This summary refers to former West Germany only. Coming to terms with the wartime past in former East Germany followed a different path (e.g. Herf 1996). As the majority of German respondents in our survey were born after 1990 and their narratives on Germany's role were similar rather than different, we do not focus on these differences in more detail.
} 
primary sources rather than teaching a monolithic version of "what really happened" (Dierkes 2005, 88-9).

In Japan, immediate post-1945 history teaching under occupation concentrated on the USJapan side of World War II to the detriment of wartime events in the rest of Asia. Moreover, as wartime Emperor Hirohito remained in office, open public discourse on Japan's World War II past was limited until the Emperor's death in 1989. The 1990s saw greater reflection on Japan's wartime deeds and the inclusion of the Nanjing Massacre as well as so-called "comfort women" into history textbooks. Still, Japan's engagement with its past is fluctuating and appears to depend on the agenda of the respective Prime Minister in charge. The government led by Shinzo Abe, in office since December 2012, has set itself the task of changing "mistaken views about Japan's wartime actions" and cultivating a more "positive" version of Japan's national narrative (Fackler 2015). This is to be achieved by dropping critical references to Japan's wartime atrocities from the national WW II narrative in Japanese education and history textbooks. Moreover, Japanese textbooks tend to narrate history in chronological and "neutral" ways by excluding open discussion of controversial topics as well as engagement with diverse primary sources (Dierkes 2010, 103-109). History education is characterized by "rote learning", encouraging memorization through repetition (Nishino 2011, 29). This approach is considered most suitable to prepare students for the "exhaustive recall of facts" demanded by university and high school entrance exams (Nishino 2011, 33; Cave 2002, 633-4). This brief overview serves as an important background on the different national understandings that inform student learning - and will help us assess to what extent students reproduce these official narratives, retell or challenge them. Before we present student responses, we develop our analytical understanding of narratives.

\section{Narrative components and conflict knowledge}

When individuals, whether they are part of political elites, bureaucrats, members of civil society organizations, or "ordinary" people talk about past and present conflicts, they frequently recur on the narrative form. In other words, they tell stories. These narratives provide ways of dealing with the past, of making the present intelligible and of looking toward the future. In doing so, narratives provide essentially selective explanations about the course of conflicts, which events are crucial to make sense of them, who their main 
agents are, and what actions are needed to resolve them. In addressing these questions, narratives contribute to creating and perpetuating different versions of social reality and thereby affect what we think we know about past or current conflicts (Delgado 1989). In alluding to the necessity of interpretation by including elements of fictionalization, narratives as analytical concepts highlight the essential constructedness of what counts as (historical) conflict knowledge. They also enjoy pride of place as a central format of organizing human experience and memory (e.g. Hoerl 2007; Sarbin 1986).

In studying narratives as analytical concepts, our research connects with an increasing number of narrative studies in International Relations (IR) (e.g. Cobb 2013; Wibben 2011; Kacowicz 2005; Suganami 1999; Kruck and Spencer 2013; Bode 2014). ${ }^{6}$ These often interdisciplinary studies have diverse aims. First, many narrative studies, sometimes building on earlier feminist research (e.g. Enloe 2014), aim to include diverging and marginalized voices into the study of international relations, expanding the confines on who count as actors and whose experiences are consequently "important" (e.g. Åhäll 2012; Shepherd 2013; Sylvester 2013). Second, in recounting these different experiences, some studies rely on the narrative as a more or less formalized concept offering new insights into the processes of social construction and look to analytical categories borrowed from literary studies (e.g. Spencer 2013; Jackson 2015). Third, narrative research often goes hand in hand with innovative methodologies on discourse analysis, designed to either get to the narratives of key protagonists or to find new ways of including the voices of the scholars themselves (e.g. Harel-Shalev and Daphna-Tekoah 2016; Brigg and Bleiker 2010; Dauphinee 2013; Martini and Jauhola 2014). Our article is situated in the context of all three aims: it highlights the voices of Japanese and German students often left out, uses a literaryinspired notion of the narrative to analyze the social construction of historical knowledge, and uses autoethnographic methods to include our day-to-day interactions and personal experiences with post-WW II remembrance. A narrative is understood as the representation of a series of events involving a number of characters and including moralistic interpretations (based on Abbott 2008, 13). ${ }^{7}$ The events that structure narratives are often

\footnotetext{
${ }^{6}$ This growing interest in narrative approaches was further underlined by the launch of the Journal of Narrative Politics in 2014.

${ }^{7}$ Narratives and stories have been defined in various ways, with the coherence and chronology of the plot as a key dividing feature (Boje 2001, 8; Wibben 2011, 59). The definition we work with serves to provide a concise conceptualisation targeted towards straightforward applicability in the context of our survey.
} 
presented in a chronological sequence forming the plot, thereby imposing a constructed linearity on the conflict process. Narratives often play with different forms of closure that coincide with a normative solution, which makes the closure offered appear more or less desirable or satisfying. The narrative plot also involves a defined set of characters, who differ in terms of their composition, action capacity and negative or positive portrayal (Bode 2015 , 49). Finally, narratives usually come with an expectation for interpretation as is implied by their character as representations. As a result, the content of narratives cannot be accessed directly but is always mediated by the way they are told including factors such as style, voice, and rhetoric devices. Despite the narrator's intent to structure narrative in such a way as to elicit a particular interpretation, narrative as a format escapes the narrator's control. The interpretative task ultimately involves the narrative's addressees who are active participants in the construction of narrative meaning (Abbott 2008, 21-2). We will now examine how these conceptual thoughts play out in student narratives about World War II.

\section{Research Methodology}

Our data on university student narratives derives from a mixed-structure online survey. While we rely on this survey in order to access student narratives about World War II, we also want to critically reflect and be open when it comes to our own, particular standpoints. Most approaches in IR/political science actively discourage personal involvement by the researcher. The more we distance ourselves from the research topic, the more the outcome is perceived as scientific or objective, however tenuous that "objectivity" is in the social sciences. However, situating ourselves within recent autoethnographic studies in IR (e.g. Dauphinee 2010; Dauphinee 2013; Doty 2010; Basberg Neumann and Neumann 2015), we agree that research is all about a person's engagement with an issue (Brigg and Bleiker 2010). Engaging in autoethnographic research essentially means explicitly including the scholar's self in academic writing and "mak[ing] it clear that writers are part of their work, part of the story they tell" (Doty 2010, 1048). By including our voices and making explicit the way these shape our interpretations explicit, "autoethnography" combines autobiography and ethnography (Guyotte and Sochaka 2016, 2). Personal experience and storytelling can therefore become legitimate and potentially important sources of insight into international relations and politics. Throughout our article, we will provide autoethnographic comments 
with brackets indicating our names to integrate a sense of self and explicate our interpretations.

\section{About the mixed-structure survey}

In the following, we, first, describe the content of the survey, second, summarize our distribution strategies and, third, present data on our respondents as well as limits of our data collection. Although the survey was anonymous, we included some general questions, such as age, study background, and university in order to ascertain the sample's diversity.

Starting with content, the survey included 19 questions, sub-divided into three parts: Part 1 concerned depth and sources of knowledge about WW II, part 2 asked students to share their narrative knowledge about WW II in more detail, and part 3 focused on reconciliation. The majority of questions were the same, although tailored to Japan/Germany respectively. We also included one distinct question in the German and two distinct questions in the Japanese survey, referring to context-specific issues. ${ }^{8}$ The survey followed a mixed-structure approach, including both multiple-choice and open-ended questions, the latter being in particular relevant to explore student narratives and perspectives on reconciliation. The empirical findings of this article only focus on a sub-set of five questions contained in part 1 and part 2 of the survey (see table 1). The average completion time for the survey was 15 minutes.

\footnotetext{
${ }^{8}$ Additional questions in the Japanese survey: "Do you know why the United States decided to drop atomic bombs on Hiroshima and Nagasaki?" and "Christian values such as forgiveness and apology partly contributed to turning mutual hatred into friendship in Europe. Is there any value you think Japan has to promote reconciliation with China and Japan?" Additional question in the German survey: "Did parts of your family originally settle in the German territories lost after the Second World War?"
} 


\begin{tabular}{|c|c|}
\hline 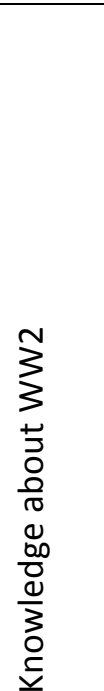 & $\begin{array}{l}\text { Q1: How would you rate your knowledge about World War II? Rating happened on a } \\
\text { scale from } 1 \text { (poor) to } 5 \text { (excellent). [Response rate: German group 79\%; Japanese group } \\
95,5 \%]^{9} \\
\text { Q2: What have been important sources of your knowledge about World War II? This was } \\
\text { a multiple choice question with eight possible answers: (1) School education; (2) university } \\
\text { education; (3) media, such as television or newspapers; (4) the Internet; (5) books; (6) oral } \\
\text { stories from parents, grandparents, family members, friends, politicians etc.; (7) visits to } \\
\text { museums or memorials; (8) other, please specify. Respondents were also asked to } \\
\text { describe the options they chose in more detail. In terms of school/university education, } \\
\text { this entailed outlining how many hours they spent learning about World War II. Students } \\
\text { were also asked to give examples for TV channels and programs they watched, books they } \\
\text { read, and memorials they visited. [Response rate: German group 100\%; Japanese group } \\
\text { 100\%]. }\end{array}$ \\
\hline 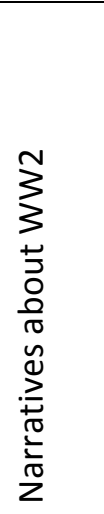 & $\begin{array}{l}\text { Q3: Was Japan/Germany a victim or an aggressor country during World War II? Students } \\
\text { were given a choice of four options: aggressor, victim, both aggressor and victim, none of } \\
\text { them, and "I don't know." [Response rate: German group 95,5\%; Japanese group 90,0\%] } \\
\text { Q4: Write down three key words or expressions that come to your mind when you hear } \\
\text { "World War II." These could be names, places, events or any other terms respondents had } \\
\text { in mind. [Response rate: German group 99,3\%; Japanese group 100\%] } \\
\text { Q5: How would you describe Japan's/Germany's role in World War II? [Response rate: } \\
\text { German group } 91,2 \% \text {; Japanese group } 76,7 \% \text { ] }\end{array}$ \\
\hline 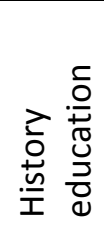 & $\begin{array}{l}\text { Q6: Should World War II history be taught differently? If yes, how? [Response rate: } \\
\text { German group } 82 \% \text {; Japanese group } 81,9 \% \text { ] }\end{array}$ \\
\hline
\end{tabular}

In terms of distribution, we shared links to the online survey among our professional networks across different universities in Germany and Japan. For a larger sampling, I (Emilia) shared the survey link on Facebook, Twitter, and official websites of research institutes in Japan. The majority of data was gathered through sharing the survey with academic colleagues. Survey respondents included mainly students from Sophia University, but also Nagoya University, Osaka University, Hokkaido University and others in the Tokyo area. I also tried to increase the number of departments and faculties in order to diversify the sample. For instance, one part of the sample includes 106 students from 12 different

\footnotetext{
${ }^{9}$ In order to allow for a high number of responses, we designed the survey in a way that allowed respondents to skip questions they did not want to answer. As a consequence, some surveys were not filled out completely. We still counted these responses as valid if the respondents completed as least half of the questions. The percentages in brackets indicate how many students of the total sample answered this particular question.
} 
departments ${ }^{10}$ in an undergraduate course entitled "Introduction to Global Studies 1" at Sophia University, Tokyo. On the German side, I (Ingvild) shared the link directly with colleagues working at German universities with social sciences, humanities and natural sciences backgrounds at the Universities of Tübingen, Hannover, Mainz, Munich, Karlsruhe und Frankfurt, while also targeting social networks. This strategy snowballed: respondents are enrolled in a total of 27 German universities across 13 out of the 16 Bundesländer. ${ }^{11}$ In total, we received 288 responses, 133 for the German survey compared to 155 for the Japanese survey. The majority of respondents across the two surveys study subjects in the areas of social sciences and humanities, with a majority of German respondents coming from a social sciences background and a majority of Japanese respondents from a humanities background (see figure 1). ${ }^{12}$

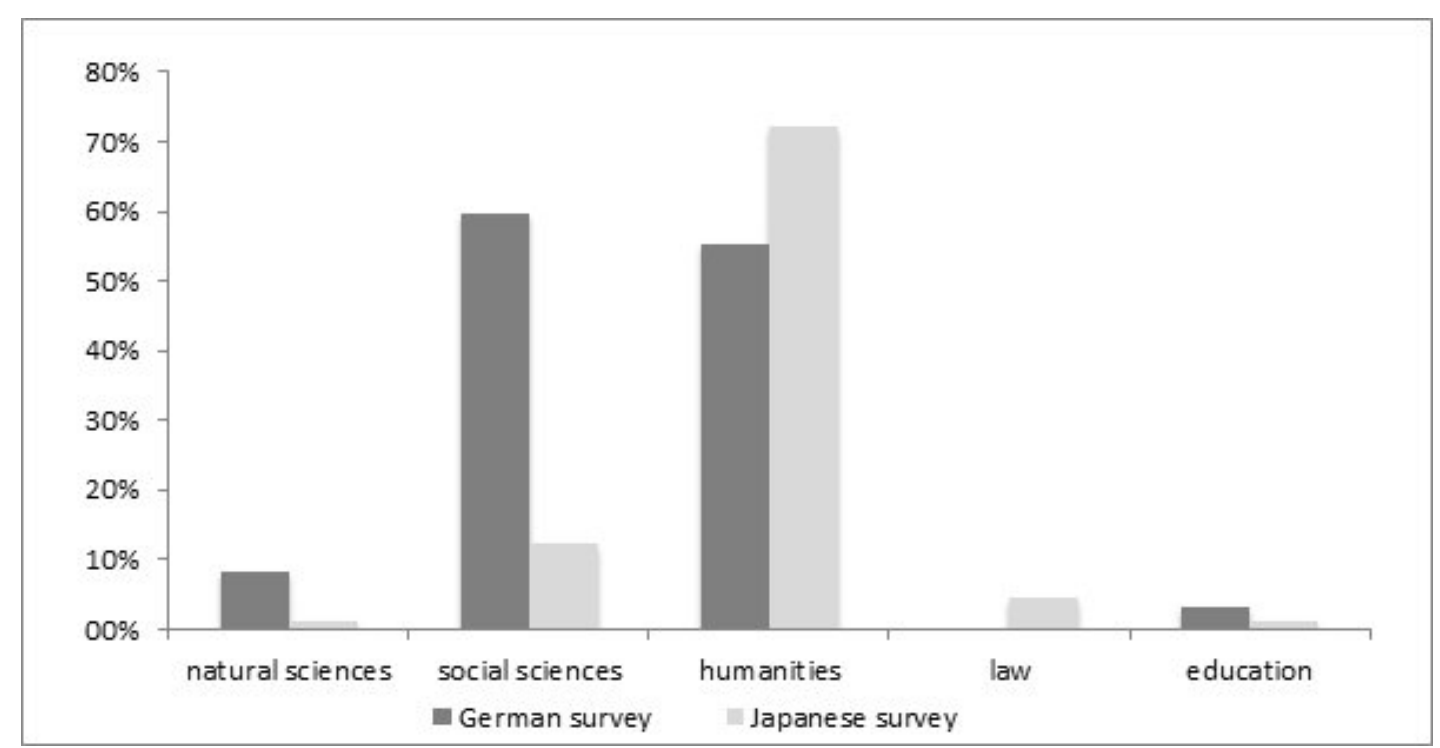

Figure 1: Respondents according to field of study

In terms of age, the vast majority of Japanese respondents are between 18-24 years of age, with only minimal numbers of respondents in some of the other age groups (see figure 2). The group of German respondents is split almost evenly among the age groups 18-24 and

\footnotetext{
${ }^{10}$ These included the Departments of English literature, French literature, German Language, Life Sciences, Management, Business Administration, Journalism, Mathematics, Engineering, Global Studies, and Liberal Arts.

${ }^{11}$ The three Bundesländer with no survey respondents are: Mecklenburg-Vorpommern, Schleswig-Holstein and Saarland.

12 Respondent answers were not limited to choosing just one field of study for this question but could instead chose several. We included this option because many B.A. students in Germany study a combination of two or more different subjects, often spanning the social sciences and humanities, e.g. politics and English literature.
} 
25-34. More of the German respondents may be current M.A. students, while the Japanese respondents are more likely to be enrolled in a B.A. program. ${ }^{13}$

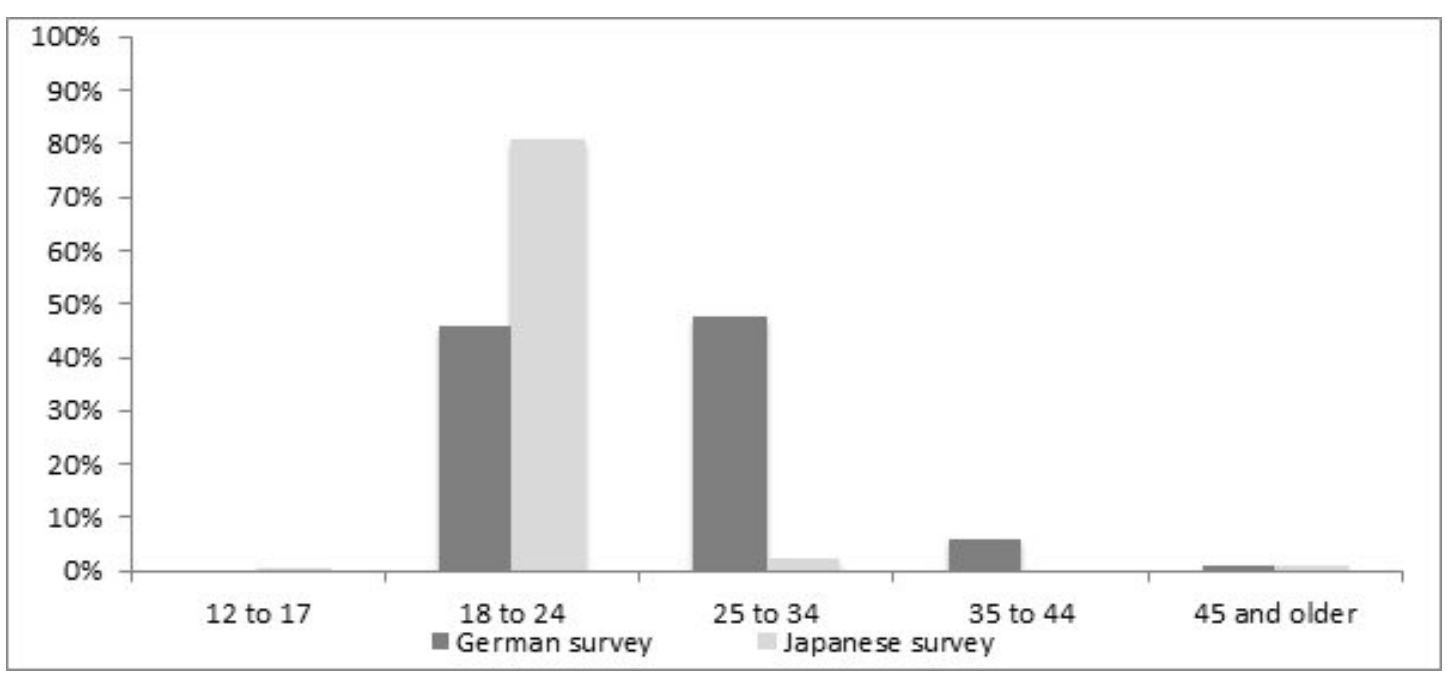

Figure 2: Age of respondents

\section{Limits of our data collection}

The comparatively small numbers of Japanese and German respondents do not allow us to engage in generalization, but they provide an indication of student narratives as a small representative sample. Although we tried to diversify this sample as much as possible, the survey still worked within certain limits. First, our survey targeted university students only as opposed to providing a comprehensive overview on youth narratives about WW II across Germany and Japan. This would have required a much larger sampling, which we deemed to be unrealistic in terms of our research timeframe and other constraints. As a result, our data remains focused on an elite youth level. Second, the survey only attracted few respondents with a natural sciences background. Although specific efforts were made to target natural sciences students, completing the survey depended on students' interest level. This element of voluntary participation, moreover, could potentially make the survey responses liable to the inclusion of a particular political agenda. However, the results do not indicate a political bias. Moreover, across both respondent groups, some students were asked either by us or

\footnotetext{
13 Because of the age split among German respondents, we cross-checked whether their age had an effect on the length of their narratives (Q5): 18-24 year olds $(N=40)$ and $25+(N=93)$. Note that these numbers only include respondents who provided answers to both Q5 and their age group. The length of narratives varied between (1) long narratives of 4+ sentences, (2) medium length narratives of 1-2 sentences, and (3) one word narratives. The differences between the two age groups point to some differences, which overall balanced themselves out: for the $18-24$ year olds (1) $15 \%$, (2) $62.5 \%$, (3) $22.5 \%$; for $25+$ (1) $22.6 \%$, (2) $35.9 \%$, (3) $41.5 \%$.
} 
by colleagues we approached through our networks to complete the surveys in class. In this way, completing the survey was not a matter of interest only.

Third, Japanese respondents are almost exclusively undergraduate students while the German group is a mixture between under- and postgraduate students. This may impose particular limits on the depth/quality of student answers. Fourth, we did not address the structural differences between the German and Japanese educational systems specifically. While Japan's educational system is more centralized, educational policy is a federal domain in Germany, resulting in qualitative and quantitative variations on how WW II history is taught. This was also remarked upon in many student responses. Despite these variations, there has been a general consensus on how Germany's WW II history should be taught starting with the Richtlinien zur Behandlung des Totalitarismus im Unterricht (Guidelines for the Treatment of Totalitarianism in Teaching) in 1962. Moreover, there were also differences in the history teaching of the former Federal Republic of Germany and the German Democratic Republic, which may be reflected in student knowledge through oral stories, although our respondents were mostly born after 1990. To address this, we compared student answers to Q5 (How would you describe Germany's role in World War II?) to assess whether responses from students born in former West Germany contained a more reflective characterization of Germany's role. However, this turned out to be insignificant as a clear majority of responses across students born in both German states included reflective characterizations. ${ }^{14}$

Finally, the survey was distributed in English and Japanese for Japanese respondents and in German only for German respondents. Japanese students were given the choice between two languages as we hoped for longer answers in the case of students responding in English. This followed the reasoning that if students lacked in language competency, they would tend to write longer answers, thereby expressing more of their thinking on narratives. Overall, English answers tended to be longer than Japanese answers, while the language students chose did not have much of an effect on the content of their narratives. All student answers were translated into English, while translations were done with sensitivity to connotations in the national discourses.

\footnotetext{
14 Narratives of students born in former East Germany were among the most sophisticated, with one narrative quoting Hanna Arendt: "The radical evil is that, what must not have come to pass, that cannot be reconciled $[\ldots]$ that one cannot pass by silently".
} 


\section{Empirical Findings}

Our findings will focus on and compare three particular aspects: first, student knowledge about WW II, second, student narratives, and third, student perspectives on their history education at school. The following section will present our empirical findings, summarizing student answers across these questions, which we will analyze and examine in light of further avenues for research.

\section{Student knowledge about World War II}

To examine student knowledge, we draw on two questions: a simple self-assessment followed by a more substantial focus on knowledge sources.

Q1 How would you rate your knowledge about World War II?15

Student assessment regarding how much they know about WW II differs greatly across the two survey groups (c. figure 3).

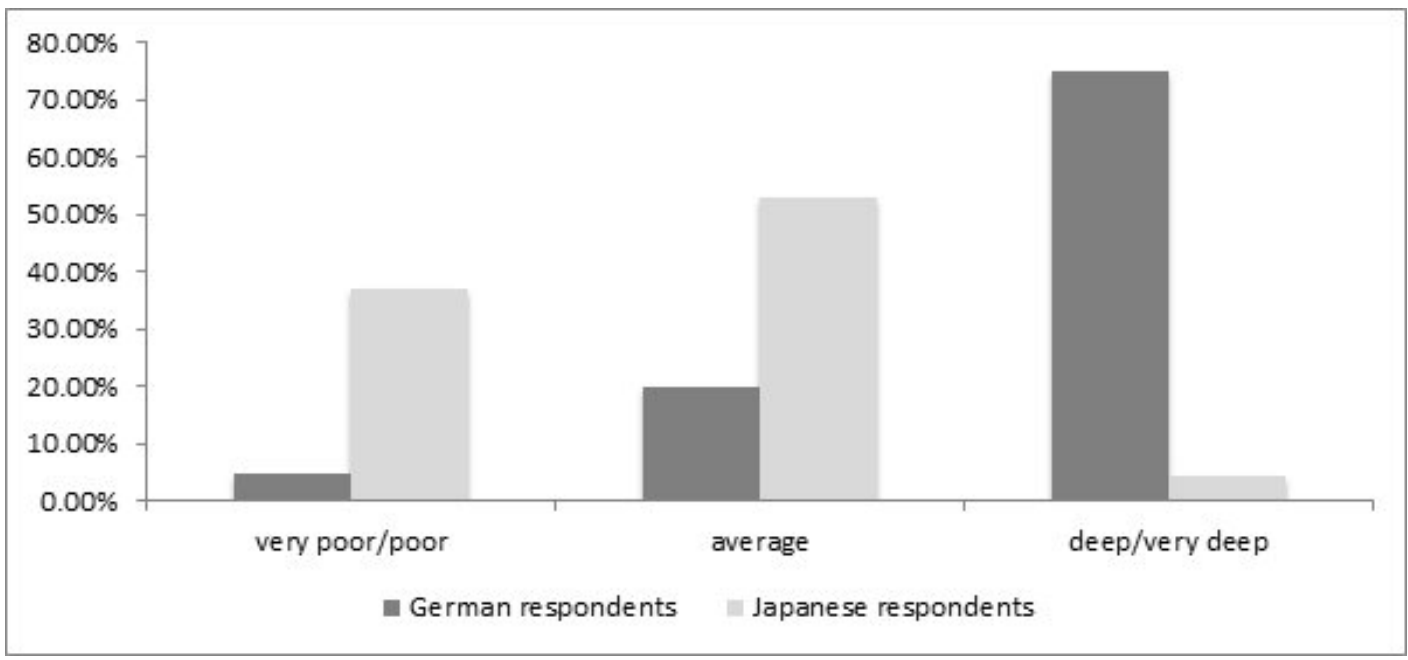

Figure 3: Q1 How would you rate your knowledge about World War II?

A clear majority of the German respondents (75\%) rate their knowledge about WW II as either "deep"/"very deep" [gut/sehr gut]. The "poor"/"very poor" [schlecht/sehr schlecht] ratings of knowledge are insignificant (5\%), while $20 \%$ rate their knowledge as average [mittel]. Half of the Japanese respondents (53\%) rate their knowledge as "average" [heikin], while another $37 \%$ chose "poor" or "very poor" [toboshii]. In other words, $90 \%$ of Japanese respondents do not think they have developed sufficient knowledge about World War II.

\footnotetext{
${ }^{15}$ Original versions: "Dai niji sekai taisenni kanshite dono kurai tishiki ga arimasuka?" and "Wie würden Sie Ihr Wissen über den Zweiten Weltkrieg insgesamt beurteilen?"
} 
The "deep"/"very deep" [hijyouni kuwashii] ratings are insignificant in the Japanese survey group (4.2\%).

These responses illustrate a gap between German and Japanese students when it comes to how they assess their WW II knowledge, although this self-assessment is highly subjective. One concern I (Emilia) had when asking this question was that Japanese students tend to be shy when it comes to judging their knowledge. From my teaching experience, I found that Japanese students say they do not know much (although they actually know a lot) as an expression of modesty. By contrast, in my experience (Ingvild), German students are likely to answer that they know a lot about World War II. Because this topic figures so prominently in history teaching and across German media/culture, most German students perhaps tend to be overly confident in their knowledge. However, our somewhat stereotyped concerns turned out to be fortunately wrong when we considered the results of the next question, which provides more substantiated information and is not as susceptible to bias.

\section{Q2: What have been important sources of your knowledge about World War II?16}

Both German and Japanese students chose high school education as the most important source of their knowledge $(93.2 \%$ to $88.3 \%$ respectively), while there were major differences between the groups with regard to two aspects. First, how much time students actually spent learning about WW II at school, and second, how this relates to other sources of knowledge students have.

WW II figured prominently in most of the German students' school careers: $31.7 \%$ noted that they spent more than 100 hours learning about World War II and another 19\% state that they find it difficult to estimate the exact number of hours as they were so many. $18.2 \%$ answered having spent 50-100 hours learning about World War II. Although these numbers may appear to be exaggerated, they correspond to my (Ingvild's) experiences in the German school system. The fact that aspects of World War II history are covered not just in history classes, but across different subjects such as literature, religion and politics/economics and are substantiated through study trips to sites remembering the Nazi past during a high

\footnotetext{
16 Original versions: "Dai niji sekai taisenni kansuru jyouhougen toshite, anatani totte jyuuyouto omowareru mono wa nandesuka? Mata sono tishiki wo dokode emashitaka?" and "Was sind wichtige Quellen Ihres Wissens über den Zweiten Weltkrieg? Sie können mehrere Antworten ankreuzen."
} 
school career, highlighted by $14 \%$ of German respondents, also helps to account for the considerable number of hours. These responses underline the central role of a multifacetted WWII education in German schools.

In comparison, $34.2 \%$ of Japanese respondents said they spent approximately eleven to twenty hours learning about World War II, while about half (52.5\%) answered less than ten hours. Among those who answered "less than ten hours", more than half noted that they spent around three to four hours during their entire high school careers. 3.5\% answered that they studied twice a week without clearly specifying to what period of time this referred. This was still the highest number of hours indicated among Japanese respondents. However, students in this group explained that they spent their high school period abroad (mainly in the United States). Further, $98.3 \%$ of Japanese students stated that they learned about World War II in history class only, Japanese history or world history, courses that often remain optional in the Japanese high school system. One of the main reasons why World War II is almost absent from the high school curriculum is its focus on seventeenthand eighteenth-century events, which are directly connected to university entrance exam content. Contemporary history is therefore only taught briefly or after preparations for the entrance exams are finished. 2.2\% of respondents also mentioned their English skills classes as a source of World War II knowledge. Two of these respondents explained that their English teachers (an American national and a British national) often brought reading materials about World War II and encouraged students to discuss in English.

Student knowledge in Germany and Japan also differs when it comes to the diversity of knowledge sources (see figure 4).

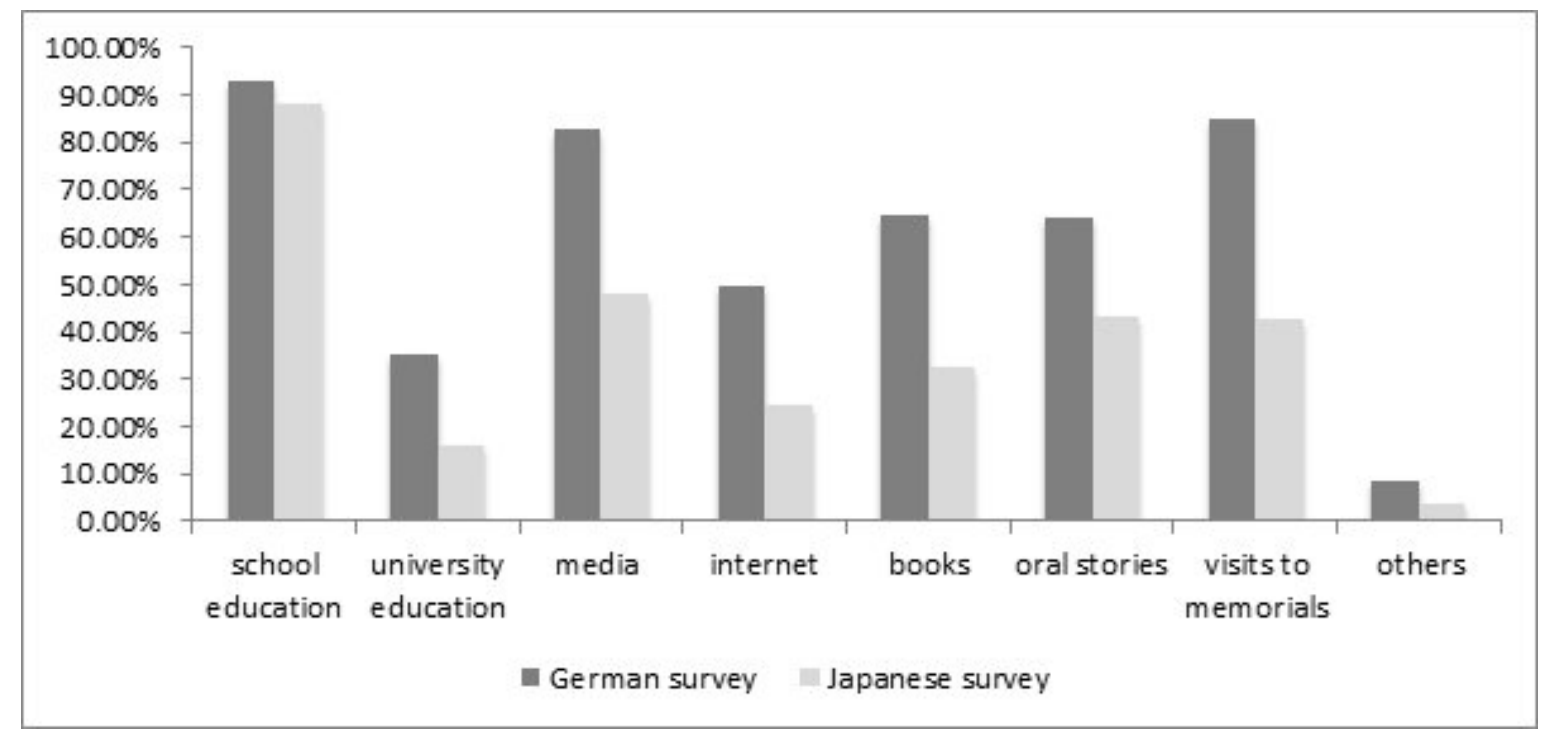


Figure 4: Q2 Sources of student World War II knowledge

More than two-thirds of German respondents checked various knowledge sources such as "visits to memorials" (85\%), "media" (82.7\%), "books" (64.7\%), and "oral stories" (63.9\%). Students were also asked to provide examples. German respondents mentioned manifold, diverse examples across all knowledge sources, which can only be summarized on a representative level in the following. In "visits to memorials", $80 \%$ of German students have visited the site of a former concentration camp, $70 \%$ the memorial to the murdered Jews of Europe in Berlin (Holocaust memorial), and 75\% a museum critically engaging with crimes of the Nazi era such as the "Topography of Terror in Berlin." In terms of "media," students mentioned sources such as newspapers, novels, documentaries, movies, podcasts and radio programs whose content generally points to a reflective portrayal of Germany's World War II past. Among the TV stations, ARD and ZDF, the two main German public TV channels as well as Arte, a joint Franco-German channel, stand out. The category of "other sources" was also ticked by almost $10 \%$ of the respondents with reference to primary sources, student exchange, and "everyday" encounters with aspects of Germany's World War II past.

In the Japanese group, knowledge sources apart from school education play a less significant role: $48.3 \%$ chose "media", $42.5 \%$ "visits to memorial/museums", and $43.2 \%$ "oral stories". When it comes to the "media", the most frequently answered source was NHK, Japan's largest national broadcasting station, followed by newspapers such as Asahi or Yomiuri, books such as the Diary of Anne Frank, and movies such as Schindler's List. Among those who chose "visits to memorials/museums," $44.2 \%$ said they have visited a museum or an exhibition about the Nagasaki/Hiroshima bombing, while $18.2 \%$ answered Okinawa Memorial Museum. Oral stories ranked third with a total of $43.3 \%$ of which $79.2 \%$ said grandfather/grandmother. Online sources also proved important with Wikipedia or Google as particularly prominent. Only $3.8 \%$ of Japanese students provided sources beyond the options given, e.g. anime.

Overall, these numbers illustrate substantial differences in the amount of time students in Germany and Japan spent learning about World War II at school and the diversity of sources their knowledge stems from. The net outcome of difference in terms of the amount of hours spent may not be that surprising. In addition, the quantity of knowledge students were exposed to does not automatically lend itself to "high quality" knowledge about World War 
II. However, students in Japan appear to have been exposed to and can therefore recur on far less diverse sources of knowledge about World War II than students in Germany. In addition, some of the key sources such as "memorials" are clearly expressions of mediated government intent and therefore representative of the overall German and Japanese knowledge environments. Upon visiting the Hiroshima Peace Memorial Museum, I (Ingvild) was struck by the lack of historical context provided. The presentation of suffering endured by the Japanese people and the long-term effects of radiation were disconnected almost entirely from WWII history and Japan's role therein. A similar presentation of World War II history appears unthinkable in the contemporary German context.

\section{Student Narratives about World War II}

To explore student narratives about World War II, we started with a general multiple-choice question to set a broad framework and then moved to content-based specific questions that allowed students to freely write their narratives. We paid particular attention to whether student narratives include a reflective characterization of their countries. A reflective characterization refers to a critical engagement with their countries' wartime past and may include value judgments, while a non-reflective characterization implies a positive-leaning engagement with no critical or diverse engagement.

\section{Q3: Was Japan/Germany a victim or an aggressor country during World War II?17}

The answers German respondents provided show an almost even divide between two options: Germany as an aggressor country (48\%) and Germany as both an aggressor and a victim of World War II (49.6\%). Minor numbers of respondents chose "none of them" (1.6\%) and "I don't know" (0.8\%), while none chose the option "victim." This even spread between perceiving of Germany as "aggressor" only and "both victim and aggressor" indicates initial reflective engagement with their country's role (see figure 5).

\footnotetext{
17 Original versions: "Nihon wa dai niji sekai taisenno higaikoku nanodeshouka, shinnryakukoku nanodeshouka?" and "War Deutschland ein Täter oder ein Opfer des Zweiten Weltkriegs?"
} 


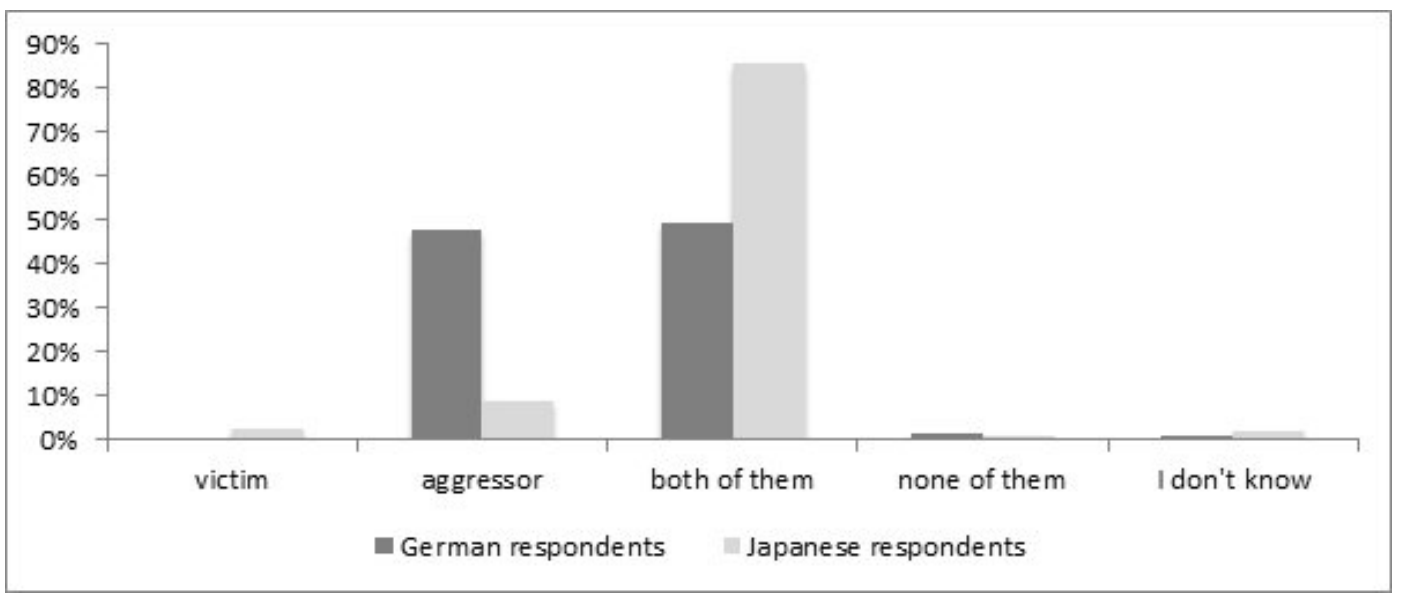

Figure 5: Q3 Was Japan/Germany a victim or an aggressor during World War II?

76.7\% of Japanese respondents answered that they consider Japan both a victim and an aggressor. While $9.0 \%$ answered only aggressor, $2.7 \%$ chose only victim. Comparable to the German case, a minor number of respondents chose "none of them" $(0.8 \%)$ and "I don't know" (1.9\%). If this categorization shows that almost $85.7 \%$ of Japanese respondents perceive their home country as having played the aggressor's role during World War II, their answers to the following two questions show surprisingly little understanding of why they categorized their country as such.

Q4: Write down three key words or expressions that come to your mind when you hear "World War II."18

Question 4 allows us to zoom in closer on how students perceive narratively of World War II. To summarize and compare our findings, we labelled German and Japanese responses according to several categories, focusing on whether these answers corresponded to an aggressor or a victim characterization. We double-coded responses to Q4, as well as those to the other open questions $(\mathrm{Q} 5, \mathrm{Q6})$ and discussed which labels/categories would be adequate at length.

For the German group, this process led to five substantial labels: aggressor, victim, resistance, value judgement, and other (see table 2).

\begin{tabular}{|l|l|}
\hline Label & \multicolumn{3}{l|}{ Sub-category/ Examples } \\
\hline Aggressor & Military, e.g. Blitzkrieg, Stalingrad, axis (34) \\
\cline { 2 - 3 }$(259 ; 67.3 \%)$ & National socialism, e.g. Nazis, NSDAP, forcible coordination \\
\hline
\end{tabular}

\footnotetext{
${ }^{18}$ Original versions: "Dai niji sekai taisennto kiite omoitsuku ki-wa-do wo mitsu agete kudasai" and "Bitte schreiben Sie drei Schlüsselworte oder -begriffe auf, die Ihnen spontan einfallen, wenn Sie 'Zweiter Weltkrieg' hören."
} 


\begin{tabular}{|l|l|}
\hline \multirow{5}{*}{} & {$[$ Gleichschaltung] (44) } \\
\cline { 2 - 2 } & $\begin{array}{l}\text { War crimes/ persecution/ concentration camps/ Holocaust, e.g. } \\
\text { Auschwitz, Reichskristallnacht, Shoa, extermination, anti-Semitism } \\
(117)\end{array}$ \\
\cline { 2 - 2 } & Hitler (64) \\
\hline Victim (16; 4.1\%) & $\begin{array}{l}\text { e.g. flight/expulsion [Flucht/Vertreibung], bombardments, air raid } \\
\text { warnings, Dresden }\end{array}$ \\
\hline Resistance (12; 3.1\%) & e.g. White Rose, Stauffenberg \\
\hline $\begin{array}{l}\text { Value judgement about } \\
\text { Germany } \\
\text { (44; } 11.4 \%)\end{array}$ & $\begin{array}{l}\text { e.g. guilt, collective guilt, genocide, catastrophe, total war, } \\
\text { propaganda, mass murder, megalomania, Vergangenheitsbewältigung }\end{array}$ \\
\hline $\begin{array}{l}\text { Other } \\
\text { (34; 8.8\%) }\end{array}$ & military, e.g. D-Day, Pearl Harbor \\
\cline { 2 - 2 } & victim, e.g. Hiroshima \\
\cline { 2 - 2 } & name, e.g. Yasukuni \\
\hline Unclear label (20; 5.2\%) & e.g. resources, history lessons \\
\hline Total answers: 385 & \\
\hline Table 2: Key World War II terms per label, German respondents \\
\hline
\end{tabular}

Q4 received a total of 385 answers, $67.3 \%$ can be labelled as "aggressor", while only $4.1 \%$ can be connected to the "victim" label and another 3.1\% relate to German resistance. 8.8\% are labelled "other" because they do not refer to Germany, but to other events or external actors. 3.3\% of answers in this category refer to Japan, mostly with regard to Hiroshima/Nagasaki. A final interesting category is "value judgements", including $11.4 \%$ of answers.

These results lead us to two findings: first, most of the terms German respondents thought of spontaneously once they heard the term "World War II" placed their home country in the "aggressor" category. This indicates a high level of critical reflection on their country's role. Second, terms that were classified in the "value judgements" category further indicate a reflective attitude towards Germany's role in World War II as they include several mentions of terms such as "guilt," "responsibility," and "genocide." Based on these spontaneous associations, the students' portrayal of their home country is much more one-sided than their responses to $\mathrm{Q} 3$ have suggested. When thinking about World War II as a whole, characterizations about Germany as both aggressor and victim become less frequent.

In the case of Japan, out of 394 key words mentioned, 55.1\% are words about Japan while $44.9 \%$ are terms about others, half of which relate to Germany and the other half refer to "general knowledge" about World War II (see table 3).

\begin{tabular}{|l|l|}
\hline Label (and numbers) & Sub-category (and numbers)/ examples \\
\hline Aggressor (19; 4.8\%) & $\begin{array}{l}\text { e.g. Nanjing massacre, Japanese Invasion of Manchuria, comfort } \\
\text { women, Hideki Tojo }\end{array}$ \\
\hline
\end{tabular}




\begin{tabular}{|l|l|}
\hline Victim $(152 ; 38.6 \%)$ & e.g. atomic bomb, Hiroshima, Nagasaki \\
\hline $\begin{array}{l}\text { Unclear label but reference to } \\
\text { Japan }(46 ; 11.7 \%)\end{array}$ & e.g. Pearl Harbor, Pacific War, Empire of Japan \\
\hline $\begin{array}{l}\text { Value judgement about war } \\
(8 ; 2 \%)\end{array}$ & $\begin{array}{l}\text { e.g. terrible, destruction, Meaningless War, huge economic loss, } \\
\text { death, loss of lives }\end{array}$ \\
\hline \multirow{2}{*}{ Germany (102; 25.9\%) } & e.g. Adolf Hitler or Hitler (49) \\
\cline { 2 - 2 } & e.g. Holocaust, Nazi Germany, Auschwitz (43) \\
\cline { 2 - 2 } & e.g. Germany or Germans, Berlin (10) \\
\hline Other (59; 15\%) & $\begin{array}{l}\text { e.g. 1939-1945, 1945, 1945.8.15, Fascism, Cold War, United } \\
\text { States, Potsdam conference, Winston Churchill }\end{array}$ \\
\hline Unclear label (8; $2 \%)$ & e.g. colonial period, Communism, Fascism \\
\hline Total answers: 394 & \\
\hline Table 3: Key World War II terms per label, Japanese respondents \\
\hline
\end{tabular}

Contrary to $85.7 \%$ respondents who classified Japan as both "aggressor and victim" and $9 \%$ as "aggressor" in Q3, only 5\% of the terms contain the notion of Japan being an aggressor. The most frequently mentioned terms concerning Japan can be found in the "victim" category (38.6\%) with answers such as the Nagasaki/Hiroshima atomic bombings. Although Nagasaki and Hiroshima-related words can be easily categorized as presenting a victimized view of Japan, we found it difficult to label the term "Pearl Harbor". While Pearl Harbor portrays Japan as a military aggressor entering into war with the United States, $87.6 \%$ of Japanese student narratives (answers to question 5) show that student perception about Pearl Harbor relies heavily on the fact that Japan had to surrender, compare for example: "At Pearl Harbor, Japan lost the war, which helped World War II come to an end." We labelled "Pearl Harbor" and other terms that referred to Japan but without a clear aggressor/victim connotation as forming a distinct category (11.7\%).

In comparison to German student responses, it is rare to find terms implying a self-reflective value judgment. The terms labelled as "value judgment" (2\%), such as "terrible" and "loss of lives" concern war in general as opposed to commenting on Japan's role. Even with regard to the terms related to Germany (25.9\%), many convey a rather generic tone, e.g. "Hitler", "Germany". A final category labelled "other" (15\%) contains terms that refer to World War II on a general level. Here students largely mentioned names, facts, events, places, and numbers without introducing any value-driven judgement. 
Q5: How would you describe Japan's/Germany's role in World War II?19

Answers to Q5 provide the most substantive assessment of how German and Japanese students narratively perceive of their country's role in World War II and whether this includes reflective or non-reflective characterizations - that is referring to negative or positive attributes and aggressor or victim qualities with regard to Germany and Japan. We came up with labels indicating various dimensions of reflection on how Germany and Japan are characterized, which differ across the student groups.

Labels attached to German student narratives range from "reflective, including value judgements" to "non-reflective/positive elements" (see table 4). There are three main results: first, a clear majority of German student narratives include some form of reflective characterization of Germany (107 out of 120). Second, looking at the different sub-divisions in this group types, many narratives can be found in the "reflective" category. Most of these (48) were one-word responses, such as "perpetrator". Thirty-three narratives were labelled as "reflective, including value judgments" because of their explicit references to German war crimes. These narratives were typically two to three sentences long, while some covered an entire paragraph. ${ }^{20}$ Third, and building on the empirical findings of Q4, only few narratives included some relativization of Germany's role (5), or blended reflective assessments with relativizing (3) or positive references (4). These three labels account for twelve out of 120 narratives, which all still contain some reflective characterization of Germany's role. Fourth, nine out of 120 student narratives are labelled as "reflective with some emphasis on victimhood". This label was attached to narratives that also referred to German victims or highlighted German resistance. In contrast to the findings of Q3, Germany for the most part comes out as "aggressor" as opposed to "both aggressor and victim" in student narratives.

\begin{tabular}{|l|l|l|}
\hline Label range & $\begin{array}{l}\text { Number of } \\
\text { narratives }\end{array}$ & Example \\
\hline $\begin{array}{l}\text { Reflective, including } \\
\text { substantive } \\
\text { judgements }\end{array}$ & $33(27 \%)$ & $\begin{array}{l}\text { "Started the war, imperialist campaign, totalitarian } \\
\text { methods, deluded racist ideals [verblendete } \\
\text { rassengeleitete Ideale] and unbelievable war }\end{array}$ \\
\hline
\end{tabular}

\footnotetext{
19 Original versions: "Dai niji sekai taisenni okeru nihon no yakuwari wa nandattanoka setsumei shite kudasai" and "Wie würden Sie Deutschlands Rolle im Zweiten Weltkrieg beschreiben?"

${ }^{20}$ Apart from one-word answers in the reflective and neutral categories, the typical length of German student narratives was 1-2 sentences.
} 


\begin{tabular}{|c|c|c|}
\hline & & $\begin{array}{l}\text { crimes, as well as crimes against humanity." } \\
\text { "Germany is the cause of World War II and } \\
\text { responsible for indescribable suffering } \\
\text { [unvorstellbaren Leidens]." } \\
\text { "Major responsibility for the outbreak of World } \\
\text { War II. Committed various atrocities [Gräueltaten], } \\
\text { e.g. the persecution of European Jews, } \\
\text { dehumanizing conduct [menschenverachtendes } \\
\text { Verhalten] with regard to the weaker members of } \\
\text { society and prisoners of war." }\end{array}$ \\
\hline Reflective & $48(39.9 \%)$ & $\begin{array}{l}\text { "aggressor"; "war monger" [Kriegstreiber]; } \\
\text { "responsible"; "guilty" }\end{array}$ \\
\hline $\begin{array}{l}\text { Reflective with some } \\
\text { emphasis on victimhood }\end{array}$ & $9(7.4 \%)$ & $\begin{array}{l}\text { "Aggressor. Responsible for unbelievable suffering } \\
\text { brought upon those that NS ideology characterized } \\
\text { as inferior, the European countries that Germany } \\
\text { invaded, and the Germans themselves." } \\
\text { "Germany started World War II and was the main } \\
\text { aggressor. Therefore, Germany bears the majority } \\
\text { of the blame [Hauptschuld]. However, one should } \\
\text { not forget that there were not only perpetrators. } \\
\text { Millions of people, many among them Germans, } \\
\text { were victims of national socialist violence } \\
\text { [nationalsozialistischer Gewalt], be they Jews, } \\
\text { political opponents, Sinti and Roma, people with } \\
\text { disabilities etc." }\end{array}$ \\
\hline Low level reflective & $10(8.2 \%)$ & $\begin{array}{l}\text { "I consider Germany as the main initiator of World } \\
\text { War II and a role model for other aggressors." }\end{array}$ \\
\hline Neutral ${ }^{21}$ & $8(6.5 \%)$ & "leading"; "at first offensive, then defensive" \\
\hline Mixed reflective/relativizing & $3(2.4 \%)$ & "Aggressor, victim of World War I" \\
\hline Relativizing & $5(4.1 \%)$ & $\begin{array}{l}\text { "Not only Germany is guilty of having caused World } \\
\text { War II. The events of World War I almost } \\
\text { automatically lead to World War II. This country's } \\
\text { racism that continues until today is, however, } \\
\text { insufferable [ein Unding]." }\end{array}$ \\
\hline Mixed reflective/positive & $4(3.3 \%)$ & $\begin{array}{l}\text { "Initially very superior. The main cause, in hit-and- } \\
\text { run style, overreached itself." }\end{array}$ \\
\hline Total no. of narratives: 120 & & \\
\hline
\end{tabular}

While German students' answers displayed various ways of understanding their past, Japanese responses were so heavily homogeneous that I (Emilia) almost thought that they copied their answers from one another while completing their survey. In fact, when we presented our initial findings at the German Institute for Japanese Studies (DIJ) in Tokyo

\footnotetext{
${ }^{21}$ The label neutral was attached to narratives that did not contain substantial value judgements pertaining to the characterisation of Germany and Japan but simply stated "facts". To note that Germany played a "leading role" in World War II or that Japan had a "huge influence" on World War II cannot be contested but does not include reflective characterisation.
} 
(July 2015), an audience member also underlined this aspect. In a private conversation after the talk she told me (Ingvild) that she recognized some of the student narratives as almost word-by-word quotes from key history textbooks.

There are four major results (see table 5):22 First, many narratives we read included a "positive/non-reflective" characterization of Japan's role during World War II (47 out of 119). Japan is frequently portrayed as the "savior" of Southeast Asian countries through assisting in liberating themselves from Western colonialism. Second, a victimized view of Japan was also prevalent in their stories, most often connected to the atomic bombings. These narrative characterizations, again, stand in contrast to the $85.7 \%$ of Japanese respondents who thought about Japan as an aggressor in Q3. Overall, these victim narratives demonstrate that many students' understanding of World War II focuses more on how Japan was bombed, lost the war, or lost lives than on the harm Japan inflicted on others. Student narratives therefore do not contain further contextual reflection about why the United States decided to drop atomic bombs. This finding is underlined by the answers to an additional question we asked in the Japanese survey only: "Do you know why the United States decided to drop atomic bombs on Hiroshima and Nagasaki?" Answers were provided by 138 out of 155 students, half of which stated "I don't know", while the other half responded along the lines of the following example: "Japan was used by the US as an experiment. I heard that the US wanted to use atomic bombs in a war to measure their effectiveness." These answers clearly characterize Japan as a victim only. While historical evaluation on Hiroshima/Nagasaki largely confirms the experimental nature of US actions, other reasons for why the atomic bombs were used, notably connected to Japan's characterization as an aggressor, appear to be unknown. Of course, one should recognize the dilemma Japanese history teachers must find themselves in given the limited amount of time allotted to teaching about World War II (compare Q2). ${ }^{23}$

\begin{tabular}{|l|l|l|}
\hline Label range & $\begin{array}{l}\text { Number of } \\
\text { narratives }\end{array}$ & Example \\
\hline $\begin{array}{l}\text { Positive or non- } \\
\text { reflective }\end{array}$ & $47(39.4 \%)$ & $\begin{array}{l}\text { "Japan helped Asian countries to become independent from } \\
\text { European countries..." } \\
\text { "Asian countries' hope because Japan tried to fight against big } \\
\text { countries such as the US." }\end{array}$ \\
\hline
\end{tabular}

\footnotetext{
22 The typical length of Japanese student narratives was 1-2 sentences. Unlike their German counterparts, Japanese respondents did not include one-word answers.

${ }^{23}$ We are indebted to an anonymous reviewer for bringing this point to our attention.
} 


\begin{tabular}{|c|c|c|}
\hline & & $\begin{array}{l}\text { "Japan wanted to represent Asia [Ajiano daihyou] / to } \\
\text { dominate Asia [Ajia shyuuhenno shihai]." } \\
\text { "Japan tried to enhance peaceful world." } \\
\text { "Japan played a role in promoting governance [touchino } \\
\text { sokushinn] by Asian people in Asia" }\end{array}$ \\
\hline $\begin{array}{l}\text { victimized or focus } \\
\text { on victimhood }\end{array}$ & $29(24.3 \%)$ & $\begin{array}{l}\text { "Japan was instrumental in WWII. We were attacked and we } \\
\text { are the only victim of atomic bomb. We are a symbol for } \\
\text { peace, I guess." } \\
\text { "Japan lost. We lost so many precious lives." } \\
\text { "Japan was beaten by the United States [Amerikani makeru } \\
\text { koto]." }\end{array}$ \\
\hline $\begin{array}{l}\text { mixed reflective } \\
\text { and positive }\end{array}$ & $11(9.2 \%)$ & $\begin{array}{l}\text { "Japan wanted to be the strongest country by invading other } \\
\text { East Asian countries but eventually failed and the atomic } \\
\text { bombs were dropped. I think Japan's role was to show you } \\
\text { must not think it is good to invade others to become the } \\
\text { center of the world." } \\
\text { "Japan played a bad role. However, I think Japan could not } \\
\text { help but doing what it did because the world itself was } \\
\text { disoriented [sekaino yugamiga atta sei]." }\end{array}$ \\
\hline reflective & $9(7.5 \%)$ & $\begin{array}{l}\text { "Japan was an aggressor just like Italy and Germany" } \\
\text { "Japan started the Second World War because of } \\
\text { overconfidence in its own power." } \\
\text { "Because Japan started the war after some irrational decisions } \\
\text { [hiriseitekina kettei], they became victimized just like other } \\
\text { countries." }\end{array}$ \\
\hline neutral & $16(13.4 \%)$ & $\begin{array}{l}\text { "Japan was one of the most important countries during World } \\
\text { War II."; "major role"; "huge influence"; "World War II leading } \\
\text { country". }\end{array}$ \\
\hline
\end{tabular}

Third, only few (9) responses clearly mentioned Japan as an aggressor while more characterized Japan in a "neutral" way, i.e. with one-word answers such as "major role". Another group of student narratives contained a mixed characterization of Japan, blending some reflection with positive aspects (11). These narratives referred not only to the relative strength of Japan and how it resisted Western imperialism but also to Japan's failure and included some value judgments on Japan's behavior in Asia. Fourth, some Japanese respondents answered with "I don't know", "I am not sure" etc. - answers that did not appear in the German survey.

\section{Student Perspectives on World War II History Education}

Our findings so far indicate a high level of respective convergence within the national World War II memory discourse in both Japan and Germany, as expressed in school education, newspapers, TV broadcasting and documentaries and museum/memorial culture, and the 
World War II knowledge and narratives Japanese or German students share. This suggests that the Japanese and German students who participated in our survey tended to reproduce their countries' official historical narratives. In this way, reasons for the differences between how German and Japanese students remember World War II can be connected to the different historical education philosophies of their countries and the diverging national remembrance cultures they are embedded in.

Despite this finding, our further conversations with German and Japanese students led us to discover that they are not as passive or "sponge-like", in the sense of simply soaking up wartime histories they are provided with, as one might wrongly believe. This critical engagement is particularly reflected in answers to question 6, which gives students the opportunity to reflect on and potentially challenge their main source of World War II knowledge - history education at school.

\section{Question 6: Should World War II history be taught differently? If yes, how?24}

Answers to this question across both student groups indicate a high level of, often critical, engagement (compare figure 6). More than half of German respondents $(58.7 \%$ or 64 answers) suggested various ways of improving World War II history education. Although a majority of students in this group supported the current reflective treatment of German history and emphasized the responsibility for remembering Germany's past, about half (31 or $48.4 \%)$ encourage the usage of different materials to enable more empathetic understanding. Suggestions for alternative materials include autobiographical accounts of Holocaust survivors, more interactive engagement through visiting memorials and exhibitions or a greater emphasis on how World War II history is relevant for understanding Germany today and for combating racism. Examples of student narratives: "History should not only be about learning the facts, as this makes World War II seem too abstract. It is important to make students aware of the fact that these are not simply numbers, but represent human beings who died. Autobiographies and diaries written by victims of the Holocausts, for example, were important for me. Further, one should not conceal what concentration camps looked like (e.g. pictures from the liberation of Auschwitz)"; "History

\footnotetext{
24 Original versions: "Dai niji sekai taisenno rekishino oshiekata wa kawaru beki deshouka? Moshi soudato sureba, dono youni kaeru bekika oshiete kudasai" and "Sollte die Geschichte des Zweiten Weltkriegs in der Schule anders gelehrt werden? Wenn ja, wie?"
} 
teaching should be diverse and comprehensive, multimedia-based, vivid. At school and outside of school. Through project groups, independent research and talking to contemporary witnesses"; "More connection to contemporary events. The pictures from back then [damals] seem like science fiction."

Another sub-group (17 or $26.6 \%$ ) criticized content-related choices, e.g. advocating a less German- and Eurocentric approach to learning about World War II or emphasizing particular aspects at length, such as why national socialism could become a politically successful project: "More international events and not only German crimes. History teaching is too Eurocentric"; "Apart from Germany, other countries and theaters of war, other nondemocratic regimes and other persecutions apart from Jews should be considered, without neglecting the unique nature of the German role/actions."

$10.9 \%$ discussed how early teaching of traumatic topics such as the Holocaust should start at school and noted the psychological challenges of coming to terms with German historical guilt, e.g.: "Not too early, e.g. only start teaching in $7^{\text {th }}$ grade. Topics such as anti-Semitism, war atrocities and concentration camps overwhelm [überfordern] students in $5^{\text {th }}$ grade." I (Ingvild) remember first watching explicit documentary material about concentration camps at age 10 in a school lesson, an experience that left me with an intense feeling of guilt that was difficult to express and comprehend.

As figure 6 also shows, $22 \%$ of German students are satisfied with the way World War II history is being taught, e.g.: "I really liked how the topic was taught during my time at school. We talked about different perspectives and discussed both the role of Germans as perpetrators and as victims. I have personally learned a lot through this approach. If current history teaching continues discussing this openly, I think this is positive." $12 \%$ suggest a less intensive treatment. Most students in this group do not dispute its general importance but criticize how the sheer volume of WWII-related topics covered may lead to oversaturation and boredom or leave less time for covering other historical epochs. Some examples: "I have to confess to being quite annoyed [genervt] by the topic during my time at school, because we kept repeating it almost once per year. My history lessons were mainly about World War I and II and the French Revolution"; "Less frequently [offensiv] across ALL subjects. Sometimes, it felt like we did not study anything else for months and months. 
Instead, I would have liked to learn more about the history of the Middle East, Russia, Asia and Africa."

In sum, these answers show a high level of support for current German history teaching, but include substantial number of critical suggestions for improving it and a thorough engagement with particular elements of historical narratives.

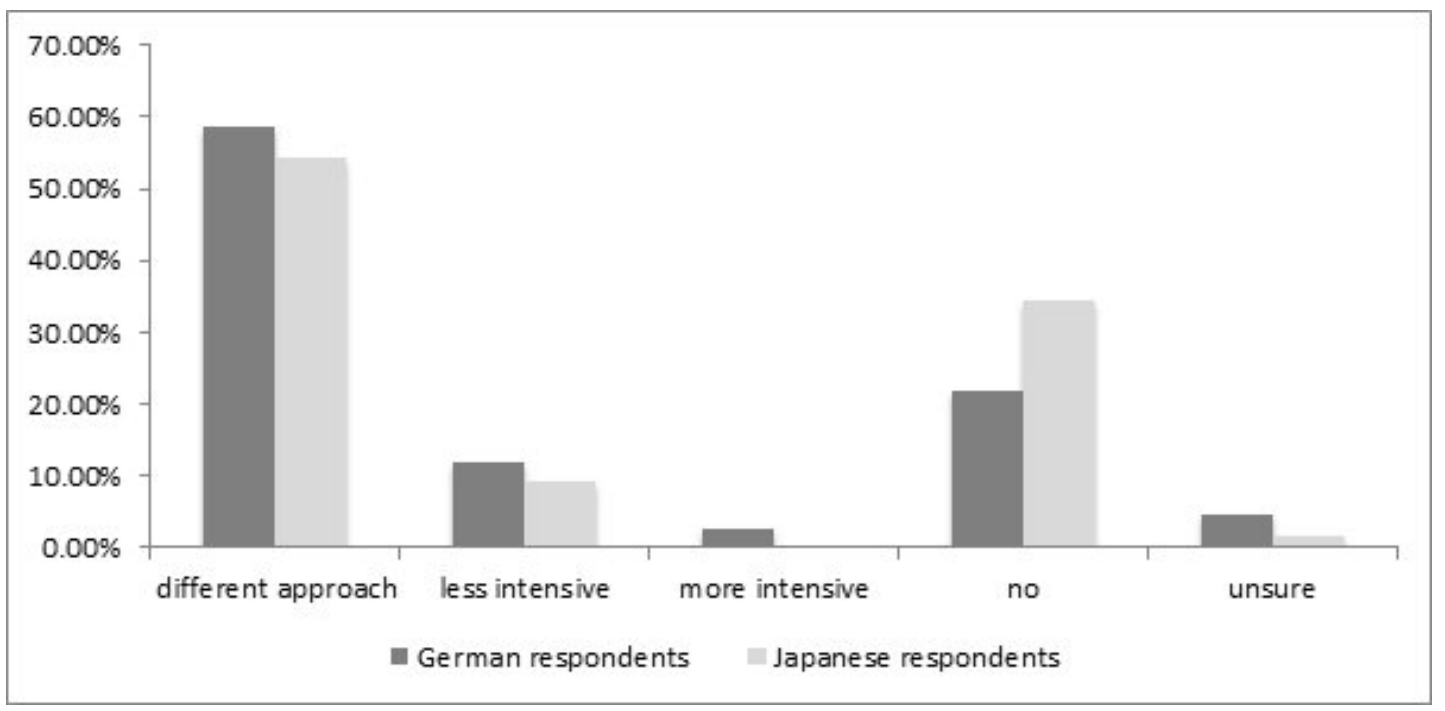

Figure 6: Should World War II history be taught differently?

Half of the Japanese students (54.3\%) think that World War II should be taught differently in Japanese schools. Many students noted that their history lessons lacked the time to think and learn about the "why" and "how" of the war, e.g.: "At school, history was generally taught for the purpose of remembering dates and events for the entrance exam. I believe that the history of World War II should be taught as a story combining issues that countries are facing today. In this way, we can learn the connection between the past and the present"; "I want to learn why the war happened"; "I simply want us to spend more time to learn"; "In Japan, world history, Japanese history, and geography are taught separately. I think we should put them together. I want to learn what my ancestors did to the world from a global perspective." Some students who studied abroad shared their comparative perspective, stating that history classes in the US or in European countries provided them with many opportunities to think critically, which was not the case in Japan. 9.4\% noted that Japanese history education focuses too much on a victimized image of Japan and does not really help them to learn the "real story", the "hidden story", or "why we were bombed": "I think we should also learn the fact that Japan was an aggressor [nihon ga shinnryakukokude aruto iu jissai] and not only emphasize that we were victimized [higai wo kyoutyou suru]"; "I 
did not know that there are various ways of looking [hukusuuno mikataga aru koto] into the past. I wish I learned various stories, including the aggressor one, not one single story". Within this group, eight $(72.2 \%)$ students said that they would like to hear the voices of comfort women, the victims of the Nanjing massacre, or any other colonized countries' stories through primary material. Two students encouraged a new way of teaching but think it is impossible for a country to teach how "aggressive" or "criminal" they were in the past. Some students said that we should stop focusing on how cruel Japan was during the war [nihon no zannkokusei bakari kyoutyou subekide wa nai] and highlight more how terrible it is to be bombed.

These answers show a high level of support for changing the way history is currently taught in Japanese high schools, especially with regard to increasing the volume of World War II history teaching. Interestingly, only very few respondents echo the Abe government's agenda encouraging a more "positive" portrayal of Japan's past. However, a large number of students also answered "no" (34.6\%). While most of these did not provide further explanations, $12.2 \%$ of respondents said they are satisfied with the "neutral" way history is being taught, focusing only on facts, events, names, and numbers: "We should learn only about objective facts (kyakkantekina jijitsu)."; "It is impossible to find a right way to teach modern history. Whoever writes it, it will be always biased." In sum, Japanese student answers show two contrasting ways of thinking about history education: some think teaching history as factual is dangerous as it does not allow students to deepen their understanding about the past and connect this to the world they live in. Others argue that critical thinking or reflection of history is unnecessary and only facts, events, and numbers matter.

\section{Conclusion}

Based on the assumption that what counts as historical conflict knowledge is socially constructed and subject to governmental interventions thus creating official accounts, this article analyzed university student narratives about World War II history in Germany and Japan. Working with a basic definition of narratives as a representation of events involving a number of characters and including moralistic interpretations, we focused on whether these narratives characterize students' home countries in reflective or non-reflective terms and whether students reproduce governmental narratives. After situating this article in the 
context of a growing number of narrative studies in IR, we presented the empirical data our study is based on: a mixed-structure online survey that received responses from 133 German and 155 Japanese enrolled university students. Based on our detailed discussion of empirical findings, we reach three concluding arguments on Japanese and German student narratives about World War II.

First, there is a gap when it comes to World War II history among German and Japanese students, both in terms of depth and sources of knowledge. Second, exposure to diverse sources of knowledge appears to lead to more varying characterizations of their home country, especially when it comes to reflecting on roles in World War II. We found a more diverse set of narratives among German students compared to less diverse, more repetitive narratives among Japanese students. This finding can be connected to a two-fold explanation: first, reflective narrative characterizations appear to be linked to having encountered diverse sources of knowledge and integrating them into a cohesive outlook. Through engaging with diverse sources, students are more likely to come across inconsistencies, different facts and different interpretations. This may invariably lead to more reflection on this knowledge as contradictions will be encountered. Second, both German and Japanese student narratives are expressions of their countries' diverging World War II remembrance discourses and their reflection in, for example, school curricula. Our findings therefore suggest that student narratives tend to reproduce official governmental narratives. Simply put, German student narratives are based on deeper knowledge and more diverse sources not only because German history education puts considerable emphasis on teaching World War II in a reflective fashion but because this is also distinctly expressed throughout German media and society. Japanese students often share more homogeneous and non-reflective characterizations of Japan in WWII, because the Japanese government puts less quantitative emphasis on teaching WWII history and history teaching relates narrated "facts" rather than inspiring critical engagement. In many ways, Japanese students are in fact denied the opportunities to develop their own, critical thinking and their own narratives on WWII because neither their curriculum, nor pedagogy encourage this. ${ }^{25} \mathrm{~A}$ tendency towards less diverse and less reflective stances is mirrored in Japanese WWII discourse across mainstream media and key parts of society.

\footnotetext{
${ }^{25}$ We are indebted to an anonymous reviewer for making this point.
} 
Our third concluding argument challenges this unidirectional "learning" of governmental narratives. When asked whether they would change how World War II history is taught at school, respondents across Germany and Japan put forward a wide range of suggestions: materials used, content covered, the relative role World War history should take in comparison to other historical epochs and psychological consequences of coming to terms with home country atrocities. This points to highly reflective engagement with World War II history and knowledge, as well as student awareness of its continued relevance for understanding their countries' policies today. Moreover, a remarkable majority of Japanese respondents express the desire to increase the volume of World War II history teaching at school.

Our survey demonstrated a clear link between how WWII history is taught in high schools and how students remember it at university. Since having started our joint research, we feel a growing sense of responsibility in problematizing what counts as knowledge, not only as scholars but also as lecturers/professors of global studies and international relations. Pedagogically, our research findings highlight the challenges of IR and history teaching at higher education institutions: What counts as historical knowledge? Where does our (historical) knowledge come from? How can using different sources lead to varying perspectives? How do national historical environments and discourses affect what can be said and thought? How can countries address negative aspects of their history "truthfully"? How can our teaching affect students' perceptions about World War II or other historical events when students are so influenced by their government's national narratives?

The findings presented in this article also open up areas for expanding research in at least two directions: First, we plan to explore and analyze student narratives about World War II across more countries and to specifically conduct surveys with university students in Poland and the Republic of Korea whose narratives would present a valuable addition to our current research findings. Extending on the survey, we also aim to conduct interviews with selected university students across the four countries. Although the survey responses capture a more representative overview of student perspectives, interviews would allow us to develop a deeper sense about students' narrative knowledge. Second, in order to gain overall insight into how societies in Japan and Germany remember World War II narratively, a generational comparison should be conducted. This would allow researchers to uncover how understanding or remembrance of their countries' wartime pasts has changed over 
time. Both research directions emphasize the importance of gathering narratives directly from people rather than relying only on analyzing discourse.

Finally, we also aim at examining reconciliation through a narrative perspective: this article only summarized a sub-set of our survey questions. Another part of the survey dealt explicitly with reconciliation and peace. Here, we aim to explore to what extent the degree and diversity of World War II knowledge sources students are exposed to influences the ways in which they perceive current relations with neighboring countries. In addressing these questions, we hope that our research on narratives and reconciliation can provide useful insights to countries still dealing with the legacy of World War II today.

Our engagement with these narrative questions through our teaching and research activities serves as a highly practical as well as normatively challenging exercise for illustrating constructivism. In this regard, the contested character of narratives, illustrative of the contingency of meaning, challenges methodological, theoretical and political orthodoxies. Narrative analysis as an approach within social sciences therefore offers comprehensive access to the multitude of realities (re-)produced by the manifold voices bridging the past and the present.

\section{References}

Abbott, Horace Porter. 2008. The Cambridge Introduction to Narrative. 2nd ed. Cambridge: Cambridge University Press.

Åhäll, Linda. 2012. "The Writing of Heroines: Motherhood and Female Agency in Political Violence." Security Dialogue 43 (4): 287-303. doi:10.1177/0967010612450206.

Anderson, Benedict. 1983. Imagined Communities: Reflections on the Origins and Spread of Nationalism. London: Verso Edition.

Apple, Michael W. 1988. Teachers and Texts: A Political Economy of Class and Gender Relations in Education. New York and London: Routledge.

- - . 2002. Education and Power. 2nd edition. New York and London: Routledge.

Basberg Neumann, Cecilie, and Iver B. Neumann. 2015. "Uses of the Self: Two Ways of Thinking about Scholarly Situatedness and Method." Millennium-Journal of International Studies 43 (3): 798-819.

Benedict, Ruth. 1946. The Chrysanthemum and the Sword: Patterns of Japanese Culture. Boston: Houghton Mifflin Company.

Berger, Thomas U. 2012. War, Guilt, and World Politics after World War II. Cambridge: Cambridge University Press.

Bindenagel, JD. 2006. "Justice, Apology, Reconciliation, and the German Foundation: 'Remembrance, Responsibility and the Future.'” In Taking Wrongs Seriously: Apologies and Reconciliations, edited by Elazar Barkan and Alexander Karn, 286-310. Stanford, CA: Stanford University Press. 
Bode, Ingvild. 2014. "Storytelling in Den Vereinten Nationen: Mahbub UI Haq Und Menschliche Entwicklung." In Politische Narrative: Konzepte - Analysen Forschungspraxis, edited by Frank Gadinger, Sebastian Jarzebski, and Taylan Yildiz, 339-62. Wiesbaden: Springer.

- - . 2015. Individual Agency and Policy Change at the United Nations: The People of the United Nations. London: Routledge.

Boje, David M. 2001. Narrative Methods for Organizational and Communication Research. London: Sage.

Brigg, Morgan, and Roland Bleiker. 2010. "Autoethnographic International Relations: Exploring the Self as a Source of Knowledge." Review of International Studies 36 (03): 779-98. doi:10.1017/S0260210510000689.

Buruma, Ian. 1995. The Wages of Guilt: Memories of War in Germany and Japan. London: Vintage.

Cave, Peter. 2002. "Teaching the History of Empire in Japan and England." International Journal of Educational Research 37 (6-7): 623-41.

- - . 2013. "Japanese Colonialism and the Asia-Pacific War in Japan's History Textbooks: Changing Representations and Their Causes." Modern Asian Studies 47 (2): 542-80.

Chirot, Daniel, Ki-uk Sin, and Daniel C. Sneider, eds. 2014. Confronting Memories of World War II: European and Asian Legacies. Seattle, WA: University of Washington Press.

Cobb, Sara B. 2013. Speaking of Violence: The Politics and Poetics of Narrative Dynamics in Conflict Resolution. Oxford: Oxford University Press.

Conrad, Sebstian. 2003. "Entangled Memories: Versions of the Past in Germany and Japan, 1945-2001." Journal of Contemporary History 38 (1): 85-99.

Dahl, Elizabeth S. 2008. "Is Japan Facing the Past? The Case of Japan." In The Age of Apology: Facing Up to the Past, edited by Mark Gibney, Rhoda E. Howard-Hassman, Jean-Marc Coicaud, and Niklaus Steiner, 241-58. Philadelphia, PA: University of Pennsylvania Press.

Dauphinee, Elizabeth. 2010. "The Ethics of Autoethnography." Review of International Studies 36 (3): 799-818.

- - . 2013. The Politics of Exile. Abingdon, Oxon: Routledge.

Delgado, Richard. 1989. "Storytelling for Oppositionists and Others: A Plea for Narrative." Michigan Law Review 87 (8): 2411-41.

Dierkes, Julian. 2005. "The Decline and Rise of the Nation in German History Education." In The Nation, Europe and the World. Textbooks and Curricula in Transition, edited by Hanna Schissler and Yasemin Nuhoglu Soysal, 82-104. New York and Oxford: Berghahn Books.

-- - 2010. Postwar History Education in Japan and the Germanys: Guilty Lessons. London \& New York: Routledge.

Doty, Roxanne Lynn. 2010. "Autoethnography - Making Human Connections." Review of International Studies 36 (4): 1047-50. doi:10.1017/S026021051000118X.

Durand, Jean-Louis, and Sebastian Kaempf. 2014. "Reimagining Communities: Opening up History to the Memory of Others." Millennium 42 (2): 331-53.

Enloe, Cynthia. 2014. Bananas, Beaches and Bases: Making Feminist Sense of International Politics. 2nd edition. Berkeley, CA: University of California Press. http://www.ucpress.edu/book.php?isbn=9780520279995.

Fackler, Martin. 2015. "U.S. Textbook Skews History, Prime Minister of Japan Says." The New York Times, January 29. 
http://www.nytimes.com/2015/01/30/world/asia/japans-premier-disputes-ustextbooks-portrayal-of-comfort-women.html.

Feldman, Lily Gardner. 2012. Germany's Foreign Policy of Reconciliation: From Enmity to Amity. Lanham, MD: Rowman \& Littlefield.

Gibney, Mark. 2008. The Age of Apology: Facing Up to the Past. Philadelphia, PA: University of Pennsylvania Press.

Guyotte, Kelly W., and Nicola W. Sochaka. 2016. "Is This Research? Productive Tensions in Living the (Collaborative) Autoethnographic Process." International Journal of Qualitative Methods 15 (1): 1-11.

Hansen, Lene. 2006. Security as Practice: Discourse Analysis and the Bosnian War. London: Routledge.

Han, Un-suk, Takahiro Kondo, Biao Yang, and Falk Pingel, eds. 2012. History Education and Reconciliation: Comparative Perspectives on East Asia. Frankfurt am Main: Peter Lang.

Harel-Shalev, Ayelet, and Shir Daphna-Tekoah. 2016. "Bringing Women's Voices Back in: Conducting Narrative Analysis in IR." International Studies Review Advance Access. doi:http://dx.doi.org/10.1093/isr/viv004.

Hein, L, and M Selden, eds. 2000. Censoring History: Citizenship and Memory in Japan, Germany, and the United States. Armonk, NY: M.E. Sharpe.

Hein, Patrick. 2010. "Patterns of War Reconciliation in Japan and Germany. A Comparison." East Asia 27 (2): 145-64. doi:10.1007/s12140-010-9106-z.

Heo, Seunghoon Emilia. 2012. Reconciling Enemy States in Europe and Asia. Basingstoke, Hampshire: Palgrave Macmillan.

Herf, Jeffrey. 1996. Divided Memory: The Nazi Past in the Two Germanys. Cambridge, MA: Harvard University Press.

He, Yinan. 2009. The Search for Reconciliation: Sino-Japanese and German-Polish Relations since World War II. Cambridge: Cambridge University Press.

Hobsbawm, Eric J., and Terence Ranger, eds. 1983. The Invention of Tradition. Cambridge: Cambridge University Press.

Hoerl, Christoph. 2007. "Episodic Memory, Autobiographical Memory, Narrative: On Three Key Notions in Current Approaches to Memory Development." Philosophical Psychology 20 (5): 621-40.

Jackson, Richard. 2015. "Terrorism, Taboo, and Discursive Resistance: The Agnostic Potential of the Terrorism Novel." International Studies Review 17 (3): 396-413.

Kacowicz, Arie M. 2005. "Rashomon in the Middle East: Clashing Narratives, Images, and Frames in the Israeli-Palestinian Conflict." Cooperation and Conflict 40 (3): 343-60.

Kruck, Andreas, and Alexander Spencer. 2013. "Contested Stories of Commercial Security: Self- and Media Narratives of Private Military and Security Companies." Critical Studies on Security 1 (3): 326-46.

Lebow, Richard Ned, Wulf Kansteiner, and Claudio Fogu, eds. 2006. The Politics of Memory in Postwar Europe. Durham, NC: Duke University Press.

Lind, Jennifer M. 2008. Sorry States: Apologies in International Politics. Ithaca, NY: Cornell University Press.

Martini, Ermina, and Marjaana Jauhola. 2014. "Journeys in Aidland: An Autobiographic Exploration of Resistance to Development Aid." Journal of Narrative Politics 1 (1): 76-96. 
Maull, Hanns W. 1990. "Germany and Japan: The New Civilian Powers." Foreign Affairs 69 (5): 91-106.

Nishino, Ryota. 2011. Changing Histories: Japanese and South African Textbooks in Comparison (1945-1995). Studien Des Georg-Eckert-Instituts Zur Internationalen Bildungsmedienforschung 129. Goettingen: V \& R unipress.

Nozaki, Yoshiko. 2008. War Memory, Nationalism and Education in Postwar Japan, 1945 2007: The Japanese History Textbook Controversy and lenaga Saburo's Court Challenges. London: Routledge.

Olick, Jeffrey K., and Daniel Levy. 1997. "Collective Memory and Cultural Constraint: Holocaust Myth and Rationality in German Politics." American Sociological Review 62 (6): 921-36.

Rose, Caroline. 2008. "Sino-Japanese Relations after Koizumi and the Limits of 'New Era' Diplomacy." In China, Japan and Regional Leadership in East Asia, edited by Christopher M. Dent, 52-64. Cheltenham: Edward Elgar.

Sarbin, T.R., ed. 1986. Narrative Psychology: The Storied Nature of Human Conduct. New York: Praeger.

Shenhav, Shaul R. 2006. "Political Narratives and Political Reality." International Political Science Review 27 (3): 245-62.

Shepherd, Laura J. 2013. Gender, Violence and Popular Culture: Telling Stories. London: Routledge.

Soysal, Yasemin Nuhoglu. 2000. "Identity and Transnationalisation in German School Textbooks." In Censoring History: Citizenship and Memory in Japan, Germany and the United States, edited by Laura Hein and Mark Selden, 127-49. Armonk, NY: M.E. Sharpe.

Spencer, Alexander. 2013. "Romantic Stories of the Pirate in IARRRH: The Failure of Linking Piracy and Terrorism Narratives in Germany." International Studies Perspectives, 116.

Suganami, Hidemi. 1999. "Agents, Structures, Narratives." European Journal of International Relations 5 (3): 365-86.

Sylvester, Christine. 2013. War as Experience: Contributions from International Relations and Feminist Analysis. London: Routledge.

Wibben, Annick T. R. 2011. Feminist Security Studies. A Narrative Approach. London: Routledge. 